\title{
Estimation of the J-Curve: An Empirical Analysis Based on the Trade Balance between Australia and China
}

\author{
Sihong $\mathrm{Wu}$
}

\begin{abstract}
This paper uses an ECM model and cointegration analysis to test 19 industries that are traded between China and Australia using the annual data over the period of 1990 to 2016 to estimate the short-run J-Curve effects and the long-run $J$-Curve effects. Results show that 13 out of 19 industries can be proved with the short-run J-Curve effects and only 4 industries are proved with the long-run J-Curve effects. This paper finds that due to the time lag effect, the devaluation of Chinese Yuan has little or no long-run effects on the trade balance between China and Australia. Thus, if there is an abnormal fluctuation of exchange rate, the trade balance will not be affected significantly.
\end{abstract}

Index Terms-Balance of trade, real exchange rate, J-Curve, ECM.

\section{INTRODUCTION}

After the devaluation of the domestic currency, the imports of the country will increase and its exports will decrease. Only after a period of time, the trade balance will be improved. This is so called the $\mathbf{J}$-Curve effects in international trade. China and Australia are closely interdependent trading partners and their trade structures are highly complementary. After signing the China-Australia Free Trade Agreement in 2014, the bilateral trade between the two countries has developed rapidly and the total volume of imports and exports has been continuously increasing. However, due to the impact of exchange rate fluctuations, the bilateral trade between China and Australia also becomes imbalances. This is a worth pondering question whether the J-Curve effect can be verified under the influence of CNY - AUD exchange rate fluctuations. Previous studies failed to mention the links between Chinese exchange rate and its trade balance with other countries of the the world. The purpose of this article is to examine the relationship between the real exchange rate and the trade balance between China and Australia.

According to the information provided by the Australian Bureau of Statistics, the trading amount between China and Australia has developed rapidly. China is Australia's largest trading partner, the largest export partner and the largest partner of imports for many years. Minerals have always been Australia's main export products to China. Textiles and raw materials are Australia's second largest exporter to China. Till March 2017, the share of Australian mineral products that exports to China further increased to over $70 \%$. Therefore, the performance of mineral products on China's exports basically determines the overall performance of Australia's exports to

Manuscript received December 17, 2018; revised February 18, 2018

The author is with Management and Commerce in Murdoch University, Western Australia (sihongwu0724@ hotmail.com).
China. Overall, Australia's imports from China registered growth, slightly higher than the average increase in imports, but much lower than its increase in exports to China, which leads to a doubling of Australia's trading surplus with China in $2017^{1}$. Different industries seems to have different impacts on the trading balance. Could the relationship between China-Australia bilateral trade balance and the real exchange rate suffers from the aggregation bias? In order to answer this question, this paper disaggregate the trading flows considering 19 industries that are traded between the two countries. This paper bounds the co-integration testing approach and error-correction model (ECM) proposed by Engle and Granger (1987) [1] to test the J-Curve effects on 19 industries that are traded between China and Australia over the period of 1990 to 2016 . There are two specific questions are addressed in this paper:

1. Is the fluctuation of real bilateral exchange rate affects China-Australia trade balance?

2. Does the J-Curve effect exists both in the short-run and in the long-run?

This paper begins with the literature review on the relationship between exchange rate and trade balance, and analysis the previous studies on China's J-Curve effect and the J-Curve effect of other China's trading partners. I found that there are insufficient studies on the impact of China's devaluation on its trade balance with Australia. Previous researches cannot identify the short-run and long-run J-Curve effects on Chinese Yuan's depreciation. Part 2 and part 3 start to analysis the current devaluation of Chinese Yuan, the short-run and long-run J-Curve effects and the current trading relationship between China and Australia. Part 4 updates the current China and Australia trading situations. The empirical analysis is in part 5 and the results and suggestions are presented in part 6 . The key findings are then brought together into the conclusion and suggestion part.

\section{LITERATURE REVIEW}

The current devaluation of Chinese Yuan has resulted in a great volatility in the financial market of the world. The J-Curve effect is a tool to demonstrate that due to the adjustment lags, a country's currency depreciation worsens the trade balance in the short term, but after the lags are realized in the long run, it will improve a country's trade balance (Magee, 1973) [2]. Several studies have tried to test the link between China's trade balance and the changes in its exchange rate. Zhang (1998) analyzed the relationship between the trade balance and the exchange rate of Chinese

\footnotetext{
${ }^{1}$ Data source: Australian Bureau of Statistics
} 
yuan and found that the fluctuation of trade balance will affect its exchange rate but not vice verse [3]. Weixian (1999) found the support for China's J-Curve effect in the short run as well as in the long run by taking into account domestic and foreign income, domestic and foreign currency and the exchange rate of the Chinese trade balance [4]. Brada et al. (2004) used a reduced form trade balance model and error-correction model to test the J-Curve effect for China, while they failed to support the J-Curve phenomenon [5].

In the research methods of J-Curve, scholars have different ideas. Previous studies mainly estimates the relationship between balance of trade and real exchange rate by using OLS and 2SLS methods. However, these estimation methods are only suitable in a fixed exchange rate environment. When a flexible exchange rate regime applied, the real relationships cannot be capture by these regression model (Demirden, Pastine, 1995) [6]. Since the introduction of co-intergration test, studies are changed to use it to examine the short-run and long-run relationships between trade balance and the real exchange rate. Pesaran (1999) applied the F-test for joint significance of the lagged level variables as a sign of co integration [7]. Narayan (2005) produces new critical values for small samples, reporting an upper bound value by assuming all variables in a given model to be integrated of order one, ad a lower bound critical value by assuming that all variables are stationary [8]. George (2016) developed a theoretical model to capture the dynamics of the trade balance and the real exchange rate and found that the dynamics of the US trade balance are mostly attributed to the decline in trade costs and the movements of the real exchange rate[9]. Bahmani-Oskooee et al. (2016) suggest a significant short-run J-Curve effects of Pakistan's currency depreciation on its trade balance of 17 industries, but only 15 cases last into the long run [10]. My et al. (2017) use the ARDL model and Error Correction Model to test the short-term and long-term $\mathrm{J}$-Curve effect on the trade balance in Vietnam. Their results shows that that the J-Curve effect does not hold on the currency of Vietnam which means that the domestic currency devaluation could not improve its trade balance [11].

By expanding the list of China's trading partners, scholars have gained some new gains. Ahmad \& Yang (2004) disaggregated China's trade flows and investigated the J-Curve phenomenon at bilateral level between China and its G-7 trading partners by using an annual data over the period of 1974 to 1994, but found no supports for the co integration among the real exchange rate of Chinese Yuan and trade balance [12]. Paresh (2006) uses a monthly data from November 1979 to September 2002 and also found no supports for the short-run J-Curve effect among China-US bilateral trade balance, but the long run effects are favorable [13]. Bahmani-Oskooee \& Wang (2010) use a separate trade balance model from Pesaran et al. (2001) to test China's J-Curve effect by taking into account 13 trading partners of China, including Australia, Belgium, Canada, France, Germany, HongKong, Italy, Japan, the Netherlands, US, UK, Singapore and Thailand, they found supports for the long-run J-Curve effect but no support for the short-run effect [14].

A large number of the previous studies suggest the short-run J-Curve effects among various countries. Bahmani-Oskooee \& Zhang (2014) analysis the J-Curve effect of China's currency depreciation, considering 49 industries between China and UK. Also, they found that the currency devaluation has favorable short-run effects in most industries but only seven cases last into the long run [15]. Bahmani-Oskooee et al. (2016) examined 65 industries that trade between Malaysia and Singapore from April 2000 to December 2014, by using the linear and the nonlinear ARDL approach, they suggest that there is an evidence of short-run asymmetric J-Curve effects of exchange rate changes in almost all industries between Malaysia and Singapore [16]. Panda \& Reddy (2016) analysis the influence of the current Chinese Yuan devaluation on the dynamics of India- China trade relations to test the validity of Marshall-Lerner Condition and J-Curve Hypothesis [17]. They suggest that the recent Yuan depreciation would make Chinese exports become more competitive, which would hurt India's exports, thus, they suggest that countries can reprice the traded commodities through manipulation in the currency market to correct its deficit problem.

From the above, we can conclude that most of the studies agree with the short-run J-Curve effects. But whether the J-Curve effects can last into the long-run or not remains a mystery. There are insufficient studies on the impact of China's devaluation on its trade balance and previous studies cannot find out the short-run and long-run J-Curve effects of Yuan's depreciation.

\section{THE SHORT-TERM AND LONG-TERM J-CURVE EFFECTS}

In the short term, currency devaluation would worsen the trade balance due to various reasons. Only after the export supply and the import demand adjusted, the trade balance started to improve. The adjustment of import and export is generally considered to take six to twelve months. The time-delay effect of currency depreciation on the improvement of a country's trade balance is called the J-Curve effect $^{2}$. With the J-Curve effect, on the one hand, the appreciation of the local currency will increase the price of imported goods in terms of foreign currency, which will finally worsen its exports. On the other hand, a depreciation of the local currency will reduce the price of imported goods in terms of foreign currency, after a certain extent, it will result in an increase in imports. These analysis can be established in the long term, but in the short term, it may not be satisfied, which means it may not exits the J-Curve effect. So it is important for us to find out the short- term and long-term J-Curve effect of Chinese Yuan depreciation on the trade balance of China and Australia.

With the increasing co-operation between China and Australia, the recent depreciation of Yuan has had a certain effect on the trade balance of China and Australia. This article is going to test if Chinese trade balance with Australia responded favorably to Yuan's devaluation. And then find out the short-run and long-run J-Curve pattern in the trade balance between China and Australia. This article seeks to contribute to the study of the relationship of China-Australia trade balance and the exchange rate depreciation.

\footnotetext{
${ }^{2}$ The idea of J-Curve effect was introduced by Magee (1973) and tested Bahmani-Oskooee (1985).
} 


\section{EXCHANGE RATE AND THE CHAFTA}

In order to find out the relationship between currency depreciation and the China-Australia trade balance, we need to first analysis the fluctuation of exchange rate in the period of 2009 to 2016.

Exchange rate is defined as the ratio of price level between two countries in PPP theory. Chinese government had made great efforts for the progress of RMB exchange rate flexibility when exchange rate changed into managed floating rate in July 2005. China's economic growth slowdown in this past 5 years. China's economic growth continues to moderate. This is not unexpected. It reflects the government's policies to slow rapid credit growth, contain shadow banking, limit borrowing and reduce excess capacity in all the industry especially the real estate. Slowly economic growth indicates that the government is having the tighten regulations on the trust and inter bank assets and to check corporate and government credit demand. This tighten policy can partially offset by series of targeted and limited stimulus measures to prevent growth from slowing too much. Since the program of economic reforms in 1978, China become the word's 2rd largest economy. However, China still suffers from severe economic imbalances, rising economic inequality and aging population. Because China's government largely controls its currency movements, China's Yuan now moves as a crawling peg to the US dollar. During the past decade, this peg has been adjusted by the China's government whenever the government thinks it's necessary. For example, Chinese goods slowed during GFC, the government placed a halt on appreciation. In 2015, China announced a change to its exchange rate setting method which will take the previous trading into account.

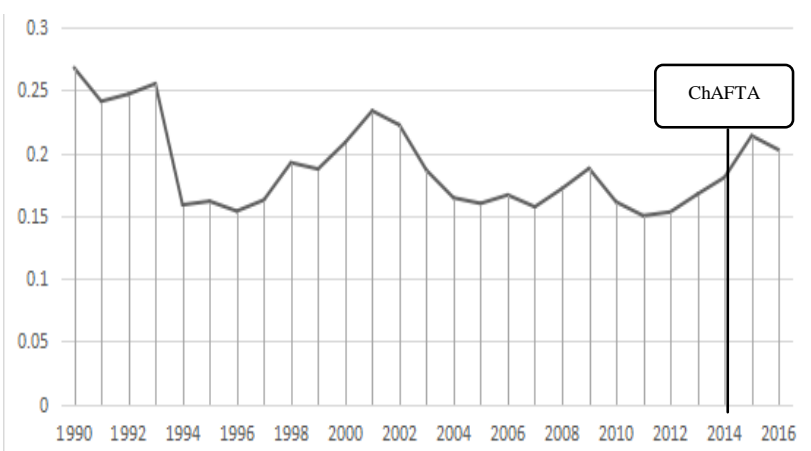

Fig. 1. Official exchange rate of AUD per CNY. Source: The World Bank

The official exchange rate of AUD and CNY fluctuates from 1990 to 2016 (See Fig. 1). The number of Australia dollar per Yuan start to drop down in 1992, and then remain stable till November 2004. Since China and Australia signed the letter of intent for the free trade agreement on November 17,2014 , at the end of the group of 20 (G20) meeting, the official AUD increase from 0.196180 to 0.222477 in 2015. China-Australia Free Trade Agreement (ChAFTA) takes effect on December 20, 2015. They start cutting trade tax on December, 2015. Australia enforced the zero-tariffs with $45 \%$ of its products immediately after it signed the agreement. On January 1, 2016, China has implemented 29.2\% of the zero-tariff products, which mainly includes drugs, medical instruments, plates, chemical products, agricultural machinery and ships, etc ${ }^{3}$.

\footnotetext{
${ }^{3}$ The ChAFTA Data comes from http://www.baike.com/wiki/
}

The Bilateral Real Exchange Rate (aka "effective exchange rate") here is the bilateral nominal exchange rate multiplied by a ratio of price indices of Australia dollar and Chinese Yuan, which can reflect their real effects on the trade balance. Thus, this paper collected the official exchange rate from the World Bank (See Fig. 1) and divided by the purchasing power parity conversion factor of China and Australia to come out with the bilateral real exchange rate (See Fig. 2). The number of Australian dollars per Yuan range between 0.15 to 0.25 from 1990-2016. There is a common phenomenon between the official exchange rate and the bilateral real exchange rate that both of them start increasing from November 2014, which is affected by the Free Trade Agreement.

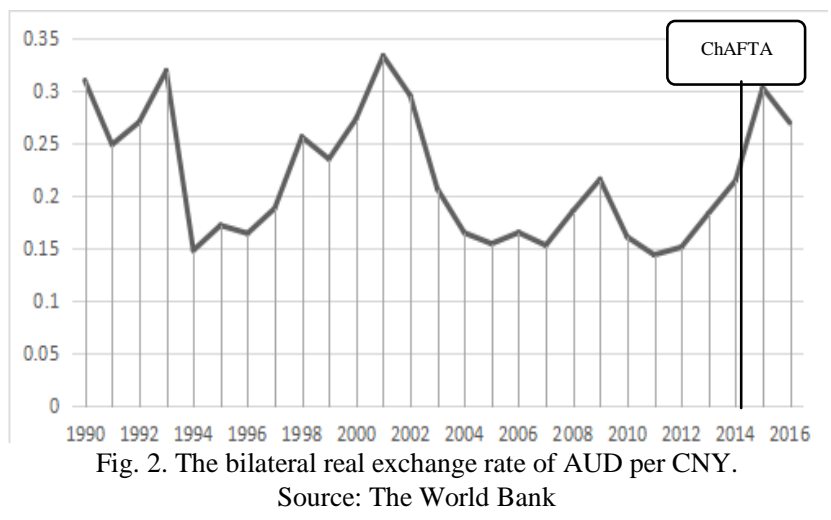

\section{BALANCE OF TRADE}

In order to find out the short- term and long- term J-Curve effects of Chinese Yuan depreciation on the trade balance of China and Australia. We need to analysis the current import and export situation of China and Australia.

\section{A. China and Australia Economic Update}

Over the long run, China would almost certainly be better off with a floating currency that can help absorb the kinds of shocks that are driving its reserve levels sharply up or down. Capital controls would have to address the dollar demand from three groups. First, with China's current account surplus growing again, there are the exporters who receive dollars in payment and prefer not to convert them to domestic currency when they fear devaluation. Second, there are the Chinese firms seeking to repay more than US\$1 trillion in dollar-denominated debt. And, finally, there are the households that still legally shift substantial funds abroad.

Today, China's current exchange rate regime is too awkward to operate for much longer without some modification. If foreign exchange reserves continue to plunge, the most likely path is a further tightening of controls, well before any large-scale devaluation or a currency float.

Australia's GDP decreased form 1,505 USD billion in 2011 to 1,205 USD billion in $2016^{4}$, which reflects a downward trend in its economy development path. Weak household income growth had a negative effect on investing in Australia. The real GDP rebounded in the December quarter 2016, increased by a stronger than expected $1.1 \%$. The bounce back was relatively broad-based across

\footnotetext{
${ }^{4}$ Source: The World Bank
} 
expenditure components. Corporate profits benefited from a surge in the terms of trade, however labour income was particularly weak. Solid economic momentum near-term will likely keep the RBA on the sidelines for much of 2017. While there is clearly spare capacity in labour and product markets, the RBA aims to balance its inflation and employment objectives against financial stability considerations, particularly given the surge in house prices in key markets in late 2016 at already high household debt levels.

\section{B. Import and Export of Goods and Services}

China's export and import of goods and services increase rapidly from 1990 to 2016 . This mainly because of the rapid development of China's foreign trade environment. On the one hand, the international economic environment China faces with is becoming better and China's domestic economy becomes more stable. On the other hand, China has strengthened trading cooperation with BRICS countries (Brazil, Russia, India, China and South Africa), "One Belt and One Road" has been steadily advancing. In the first three quarters in 2017, the import and export growth of the countries along the "One Belt And One Road" has increased by $20.1 \%$. Also, the devaluation of Chinese Yuan is one of the most important reasons for the increasing trade balance.

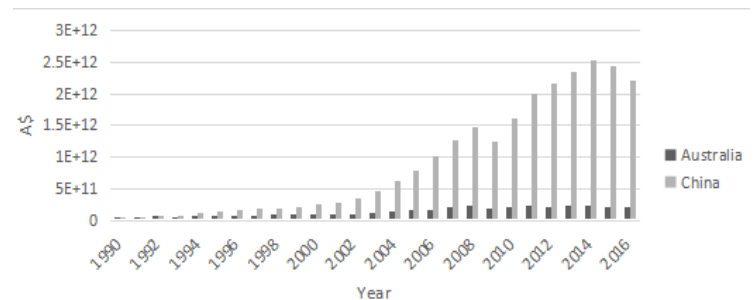

Fig. 3. Exports of goods and services from 1990-2016. Source: The World Bank

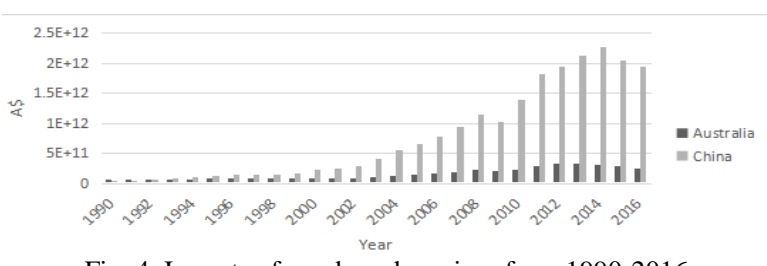

Fig. 4. Imports of goods and services from 1990-2016 Source: The World Bank

The changes of Australia's import and export of goods and services in the period of 1990 to 2016 is more stable compared with that of China. (See Fig. 3) The export of goods and services increased from 1244 billion US dollar in 2009 to 2524 billion in 2014, then decreased to 2199 billion in 2016. Same as the export trend, the import data of Australia increased dramatically from 1029 billion in 2009 to 2261 billion in 2014, then dropped a bit to 1950 billion in 2016. On January 2017, Australia's export increase $76.75 \%$ compared the export in 2009, while its import increased $89.43 \%$. (See Fig. 4) These data shows an unbalanced trade growth trends of its trade balance. The reason may due to the slower development of Australia's economy. More importantly, with the development of China-Australia trade cooperation, Australia's import and export is affected by the recent devaluation of Chinese Yuan.

\section{Balance of Trade}

The China-Australia Free Trade Agreement (ChAFTA) was announced in 2014 which is aim to broaden China and Australia's export performance and provide new opportunities to their exporters. This article is aim to prove the short-run and long-run J-Curve effects between China-Australia trade balance.

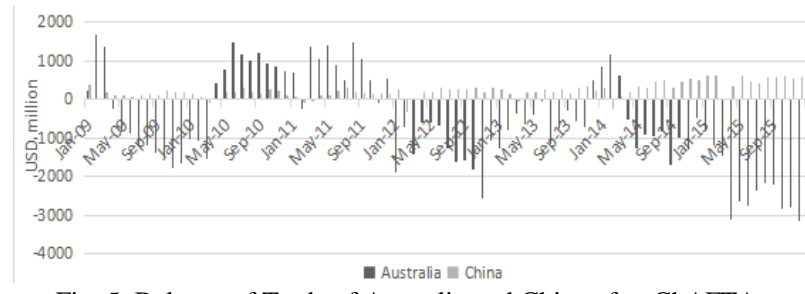

Fig. 5. Balance of Trade of Australia and China after ChAFTA.

Source: Australia Bureau of Statistics; China Bureau of Statistics

Fig. 5 shows the trade balance between Australia and China from January 2009 to December 2015. The trend of trade balance was similar in the period of Jan-09 to Apr-09, May-10 to Jan-12 and Jan-14 to May-14. However, Australia and China had an opposite trend of trade balance in the period excluded the above similar trend period.

\section{THE MODEL AND THE METHOD}

\section{A. The Model}

In formulating a trade balance model between China and Australia, this paper follow Marwad and Klein (1996) and Bahmani-Oskooee and Brooks (1999), who defined the trade balance as the ratio of imports over exports. The model could be expressed in log-linear format. Following the formulation:

$$
\operatorname{LogTB}_{t}=\alpha+\beta \log Y_{c, t}+\gamma \log Y_{i, t}+\lambda \log R E X_{t}+\zeta_{t}
$$

where, $T B$ is defined as the ratio of China's nominal imports from trading partner $i$ over China's nominal exports to the same partner. $Y C$ is the domestic income. $\beta$ is defined as the import coefficient.

A decrease in REX reflects a real depreciation of RMB, so $\lambda$ is expected to be positive. Because (1) is a long term estimation and $\mathrm{J}$-curve concept is a short term phenomenon, we need to incorporate the short term dynamics into the estimation approach. Different co-integration approaches have different error-correction specifications. For instance, following the Engle and Granger (1987) approach [1], the error-correction model will like the following form:

$$
\begin{aligned}
& \Delta \log T B_{t}=\alpha+\sum_{k=1}^{n} w_{k} \Delta \log T B_{t-k}+\sum_{k=0}^{n} \beta_{k} \Delta \log Y_{c, t-k} \\
& +\sum_{k=0}^{n} \gamma_{k} \Delta \log Y_{i, t-k}+\sum_{k=0}^{n} \lambda_{k} \Delta \log R E X_{t-k}+\delta \varepsilon_{t-1}+\omega_{t}
\end{aligned}
$$

This Equation is a standard VAR model with a addition of the lagged error term.

where, the $\varepsilon_{t-1}$ are the lagged stationary residuals from Equation (1).

Co-integration could be established if $\varepsilon_{t-1}$ carries a negative and significant coefficient.

Pesaran et al. (2001) have modified this equation by replacing $\varepsilon_{t-1}$ in an auto regressive distributed lag form as follows: 


$$
\begin{aligned}
& \Delta \log T B_{t}=\alpha+\sum_{K=1}^{n} \omega_{k} \Delta \log T B_{t-k}+\sum_{\mathrm{k}=0}^{n} \beta_{k} \Delta \log Y_{c, t-k} \\
& +\sum_{k=0}^{n} \gamma_{k} \Delta \log Y_{i, t-k}+\sum_{k=o}^{\mathrm{n}} \lambda_{k} \Delta \log R E X_{t-k}+\delta_{1} \log T B_{t-1} \\
& +\delta_{2} \log Y_{i t-1}+\delta_{3} \log Y_{j, t-1}+\delta_{4} \log R E X_{t-1}+v_{t}
\end{aligned}
$$

To test the null of no co-integration, ie., $\delta_{1}=\delta_{2}=\delta_{3}=\delta_{4}=0$ against the alternative of $\delta_{1} \neq \delta_{2} \neq \delta_{3} \neq \delta_{4} \neq 0$. Pesaran et al. (2001) propose using the $\mathrm{F}$ test with new critical values that takes into consideration the stationary properties of the variables. If the calculated $\mathrm{F}$ statistic is greater than its critical value, the null cannot be rejected and the lagged-level variables are to be retained in the Equation 3. In this case, they are said to be co-integrated.

The $\mathrm{J}$ curve effect is inferred by the sign and significance of the estimated $\lambda s$. Negative values for the first few $\lambda s$ followed by positive values will support the $J$ curve. The long term effect of real depreciation is inferred by the size and significance of $\delta_{4}$ normalized on $\delta_{1}$.

According to the method used by Bahmani-Oskooee and Wang (2008) which investigated the J-Curve effect using commodity level data between China and the US. There are three variables in determining the trade balance [14], i.e., domestic income, foreign income and the real exchange rate. In testing the J-Curve phenomenon of China-Australia trade balance, this paper use the model by changing the yields to match the case of China-Australia commodity data.

$$
\operatorname{Ln}\left(\frac{X_{\mathrm{i}}}{M_{i}}\right)=a+b \operatorname{Ln} Y_{t}^{A U}+c \operatorname{Ln} Y_{t}^{C}+d \operatorname{LnREX} X_{t}+\varepsilon_{t}
$$

In the equation (4), $X_{i}$ is the Australia's exports of commodity $i$ to China and $M_{i}$ is the Australia's imports of commodity $i$ from China. Two measures of economic activities are identified by $Y_{t}^{A U}$ (Australian income) and $Y_{t}{ }^{C}$ (Chinese income). The first measure is expected to carry a negative coefficient and the second measure is expected to have a positive coefficient. REX represents the real effective exchange rate $\left(R E X=\frac{P_{c} * N E X}{P_{A U}}\right)$, where $P_{c}$ is the price level in China and $P_{A U}$ is the price level in Australia. NEX is the nominal exchange rate defined as number of Australian dollars per Chinese yuan. In this case, an increase in REX means a real depreciation of the Australian dollar, and this will improve the trade balance of the industry $i$, so $d$ is expected to be positive. $\varepsilon$ is an error term in the equation.

If just follow equation (1) to estimate the short-run J-Curve effect, it is useless because it does not reveal any information about the short-run dynamics. Thus, this paper uses the Pesaran et al.'s (2001) bounds testing model as follows:

$$
\begin{aligned}
& \Delta \operatorname{Ln}\left(\frac{X_{i}}{M_{i}}\right)=a+\sum_{k=1}^{\mathrm{n}} \beta_{t-k} \Delta \operatorname{Ln} Y_{t-k}^{A U} \\
& +\sum_{k=0}^{n} \gamma_{t-k} \Delta \operatorname{Ln} Y_{t-k}^{C} \\
& +\sum_{k=0}^{n} \pi_{t-k} \Delta L n R E X_{\mathrm{t}-\mathrm{k}} \\
& +\lambda_{1} \operatorname{Ln}\left(\frac{X_{i}}{M_{i}}\right)_{t-1}+\lambda_{2} \operatorname{Ln} Y_{t-1}^{A U} \\
& +\lambda_{3} \operatorname{Ln} Y_{t-1}^{C}+\lambda_{4} \operatorname{LnREX}_{t-1}+\sigma_{t}
\end{aligned}
$$

The error correction model (ECMs) is a theoretically-driven method which can be used to estimated both short-term and long-term effects of one time series on another. The error influences its short-run dynamics while the last-periods deviation from a long-run equilibrium. The short-run effects are inferred by the coefficient estimates and the long-run effects are inferred by the estimates of $\lambda_{2}-\lambda_{4}$ that are normalized on $\lambda_{1}$. For details of arriving at Equation (2), see Bahmani-Oskooee and Wang (2008) [3].

\section{B. Dependent Variable}

In order to analysis how the changes of bilateral exchange rate affects the trade balance and whether there exits the J-Curve effect, this paper uses the trade balance of 19 industries that traded between China and Australia from 1990 to 2016 as the dependent variable. The trade balance is calculated by the Australia's export of commodity to China and the Australia's imports of commodity from China.

\section{Independent Variables}

The fluctuation of the bilateral real exchange rate will affect a country's trade balance and a country's income level can also affect its trade size. So, this paper uses the AUD-CNY Bilateral exchange rate, China's domestic income and Australia' domestic income as the dependent variables in order to find out the short-run and long-run J-Curve effects.

\section{Source of Data}

The 19 industries were screened from the Australia Bureau of Statistics and China Bureau of Statistics. We use the annual data (A \$000) of these industries from 1990 to 2016. Annual GDP data (A\$000) of China and Australia comes from the World Bank and the bilateral real Exchange Rate is calculated through the official exchange rate and price level which comes from the World Bank. The data over the period 1990 to 2016 are used to carry out the empirical results, including Australia exports of commodity $i$ to China and imports of commodity $i$ from China which all come from the World Bank data sources.

\section{EMPIRICAL RESULTS}

In this empirical analysis section, this paper uses the error-correction model for each of the 19 industries that trade between China and Australia using annual data over the period 1990 to 2016 to estimate the short-run J-Curve effects and the long-run J-Curve effects.

Before dealing with the time series data, this paper first consider the stationery of the data. That is, if the mean value and the co variance of the selected data changes with the changes of time, it is easy to cause errors in judgment, namely, pseudo regression. Thus, i use the Augument dickey-fuller (ADF) unit root test and found that the variables had a unit root. This paper determined the optimal lag number according to the AIC value and the non-stationary sequence difference processing was performed. The statistic analysis is provided in Table I. The Short-run and long-run coefficient estimates are reported in Table II and the results of other diagnostic statistics are reported in Table III. 
TABLE I: STATISTICS ANALYSIS

\begin{tabular}{|c|c|c|c|c|c|c|c|c|}
\hline Variables & Mean & Median & Maximum & Minimum & Std. Dev. & Skewness & Kurtosis & Jarque-Bera \\
\hline 111 & 1.49 & 1.71 & 2.68 & -2.74 & 1.24 & -1.90 & 6.66 & 31.33 \\
\hline 112 & 5.31 & 4.61 & 7.65 & 2.77 & 1.46 & 0.28 & 1.70 & 2.26 \\
\hline 113 & 4.84 & 2.88 & 15.77 & 0.00 & 4.20 & 0.89 & 3.06 & 3.61 \\
\hline 114 & 4.35 & 4.26 & 5.02 & 3.13 & 0.43 & -0.67 & 3.55 & 2.39 \\
\hline 121 & 0.50 & 0.47 & 1.57 & -0.93 & 0.55 & -0.47 & 3.55 & 1.33 \\
\hline 122 & -0.35 & 0.00 & 4.19 & -6.03 & 2.49 & -0.31 & 3.24 & 0.50 \\
\hline 123 & -0.84 & -0.30 & 3.97 & -6.21 & 2.50 & -0.44 & 2.87 & 0.88 \\
\hline 124 & 0.79 & 0.29 & 5.56 & -5.06 & 2.03 & -0.19 & 4.51 & 2.73 \\
\hline 231 & 0.91 & 0.99 & 2.23 & -0.17 & 0.56 & 0.04 & 2.60 & 0.19 \\
\hline 232 & -1.35 & -1.38 & -0.44 & -2.24 & 0.55 & -0.02 & 1.85 & 1.50 \\
\hline 233 & -1.82 & -1.66 & 1.32 & -5.88 & 2.41 & -0.21 & 1.52 & 2.68 \\
\hline 241 & -0.84 & -0.46 & 0.98 & -4.61 & 1.38 & -1.30 & 4.04 & 8.82 \\
\hline 242 & -1.02 & -0.92 & -0.59 & -2.12 & 0.36 & -1.34 & 4.63 & 11.07 \\
\hline 243 & -2.09 & -2.22 & -0.10 & -3.33 & 1.02 & 0.52 & 1.95 & 2.46 \\
\hline 244 & -4.57 & -4.61 & -4.01 & -5.52 & 0.39 & -0.48 & 2.58 & 1.21 \\
\hline 301 & 2.25 & 2.55 & 4.40 & -1.79 & 1.44 & -0.97 & 3.73 & 4.79 \\
\hline 302 & 1.91 & 0.00 & 9.20 & -4.99 & 3.49 & 0.75 & 2.76 & 2.60 \\
\hline 304 & 2.31 & 2.28 & 3.81 & 1.34 & 0.61 & 0.53 & 2.96 & 1.25 \\
\hline LNYC & 21.43 & 21.23 & 23.14 & 19.70 & 1.14 & 0.11 & 1.73 & 1.88 \\
\hline LNYA & 20.24 & 19.96 & 21.17 & 19.56 & 0.59 & 0.35 & 1.52 & 3.00 \\
\hline LNREX & -1.56 & -1.58 & -1.10 & -1.94 & 0.28 & 0.21 & 1.60 & 2.42 \\
\hline DLNREX & -0.01 & 0.06 & 0.34 & -0.77 & 0.24 & -1.22 & 4.98 & 10.68 \\
\hline D2LNREX & 0.00 & 0.13 & 0.92 & -0.93 & 0.35 & -0.28 & 4.61 & 3.02 \\
\hline D3LNREX & -0.03 & -0.03 & 1.85 & -1.11 & 0.60 & 0.97 & 5.45 & 9.79 \\
\hline
\end{tabular}

TABLE II: SHORT-RUN AND LONG-RUN COEFFICIENT ESTIMATES

\begin{tabular}{|c|c|c|c|c|c|c|c|}
\hline \multirow[b]{2}{*}{ Code } & \multicolumn{4}{|c|}{ Short-run coefficient estimates } & \multicolumn{3}{|c|}{ Long-run coefficient estimates } \\
\hline & dlnrex & d2lnrex & d3lnrex & Constant & lnya & $\operatorname{lnyc}$ & lnrex \\
\hline 111 & $\begin{array}{l}2.73 \\
(2.86)\end{array}$ & $\begin{array}{l}-0.65 \\
(2.84)\end{array}$ & $\begin{array}{l}0.08 \\
(1.07)\end{array}$ & $\begin{array}{l}14.93 \\
(25.56)\end{array}$ & $\begin{array}{l}-2.87 \\
(2.87)\end{array}$ & $\begin{array}{l}2.10 \\
(1.48)\end{array}$ & $\begin{array}{l}0.34 \\
(1.78)\end{array}$ \\
\hline 112 & $\begin{array}{l}1.37 \\
(1.09)\end{array}$ & $\begin{array}{l}-1.12 \\
(1.08)\end{array}$ & $\begin{array}{l}0.17 \\
(0.41)\end{array}$ & $\begin{array}{l}-39.08 * * * \\
(9.70)\end{array}$ & $\begin{array}{l}2.12 * \\
(1.09)\end{array}$ & $\begin{array}{l}0.04 \\
(0.56)\end{array}$ & $\begin{array}{l}-0.45 \\
(0.68)\end{array}$ \\
\hline 113 & $\begin{array}{l}-5.70 \\
(6.22)\end{array}$ & $\begin{array}{l}-6.91 \\
(6.17)\end{array}$ & $\begin{array}{l}1.44 \\
(2.32)\end{array}$ & $\begin{array}{l}-282.20 * * * \\
(55.52)\end{array}$ & $\begin{array}{l}31.11 * * * \\
(6.24)\end{array}$ & $\begin{array}{l}-14.99^{* * * *} \\
(3.21)\end{array}$ & $\begin{array}{l}13.18^{* * * *} \\
(3.87)\end{array}$ \\
\hline 114 & $\begin{array}{l}-1.47 * * \\
(0.68)\end{array}$ & $\begin{array}{l}1.39 * \\
(0.67)\end{array}$ & $\begin{array}{l}-0.45^{*} \\
(0.25)\end{array}$ & $\begin{array}{l}-10.54 \\
(6.07)\end{array}$ & $\begin{array}{l}1.058 \\
(0.68)\end{array}$ & $\begin{array}{l}-0.29 \\
(0.35)\end{array}$ & $\begin{array}{l}0.20 \\
(0.42)\end{array}$ \\
\hline 121 & $\begin{array}{l}0.30 \\
(0.94)\end{array}$ & $\begin{array}{l}0.37 \\
(0.93)\end{array}$ & $\begin{array}{l}-0.06 \\
(0.35)\end{array}$ & $\begin{array}{l}22.68 * * \\
(8.36)\end{array}$ & $\begin{array}{l}-2.33^{* * *} \\
(0.94)\end{array}$ & $\begin{array}{l}1.132 * * \\
(0.48)\end{array}$ & $\begin{array}{l}-0.47 \\
(0.58)\end{array}$ \\
\hline 122 & $\begin{array}{l}-7.13 \\
(7.34)\end{array}$ & $\begin{array}{l}4.02 \\
(7.28)\end{array}$ & $\begin{array}{l}-0.64 \\
(2.73)\end{array}$ & $\begin{array}{l}-89.38 \\
(65.55)\end{array}$ & $\begin{array}{l}6.58 \\
(7.37)\end{array}$ & $\begin{array}{l}-1.84 \\
(3.78)\end{array}$ & $\begin{array}{l}3.22 \\
(4.57)\end{array}$ \\
\hline 123 & $\begin{array}{l}13.45^{* * *} \\
(4.75)\end{array}$ & $\begin{array}{l}-5.08 \\
(4.71)\end{array}$ & $\begin{array}{l}-0.55 \\
(1.77)\end{array}$ & $\begin{array}{l}140.0 * * * \\
(42.43)\end{array}$ & $\begin{array}{c}-15.73 * * * \\
(4.77)\end{array}$ & $\begin{array}{l}7.33 * * * \\
(2.45)\end{array}$ & $\begin{array}{l}-12.77 * * * \\
(2.96)\end{array}$ \\
\hline 124 & $\begin{array}{l}1.59 \\
(2.10)\end{array}$ & $\begin{array}{l}-3.28 \\
(2.09)\end{array}$ & $\begin{array}{l}1.15 \\
(0.78)\end{array}$ & $\begin{array}{l}28.78 \\
(18.79)\end{array}$ & $\begin{array}{l}0.49 \\
(2.11)\end{array}$ & $\begin{array}{l}-1.84 \\
(1.08)\end{array}$ & $\begin{array}{l}-1.25 \\
(1.31)\end{array}$ \\
\hline 231 & $\begin{array}{l}-2.57 * \\
(1.36)\end{array}$ & $\begin{array}{l}2.25 \\
(1.35)\end{array}$ & $\begin{array}{l}-0.81 \\
(0.51)\end{array}$ & $\begin{array}{l}-22.43 * \\
(12.12)\end{array}$ & $\begin{array}{l}2.01 \\
(1.36)\end{array}$ & $\begin{array}{l}-0.65 \\
(0.70)\end{array}$ & $\begin{array}{l}2.17 * * \\
(0.85)\end{array}$ \\
\hline 232 & $\begin{array}{l}1.09 \\
(0.96)\end{array}$ & $\begin{array}{l}-0.26 \\
(0.95)\end{array}$ & $\begin{array}{l}0.08 \\
(0.36)\end{array}$ & $\begin{array}{l}29.23 * * * \\
(8.58)\end{array}$ & $\begin{array}{l}-2.75^{* *} \\
(0.97)\end{array}$ & $\begin{array}{l}1.08^{* *} \\
(0.50)\end{array}$ & $\begin{array}{l}-1.15^{*} \\
(0.60)\end{array}$ \\
\hline 233 & $\begin{array}{l}8.03 * * * \\
(2.45)\end{array}$ & $\begin{array}{l}-6.16^{* *} \\
(2.42)\end{array}$ & $\begin{array}{l}2.02 * * \\
(0.91)\end{array}$ & $\begin{array}{l}68.84 * * * \\
(21.83)\end{array}$ & $\begin{array}{l}-2.27 \\
(2.45)\end{array}$ & $\begin{array}{l}-1.40 \\
(1.26)\end{array}$ & $\begin{array}{l}-3.37 * * \\
(1.52)\end{array}$ \\
\hline 241 & $\begin{array}{l}1.65 \\
(1.39)\end{array}$ & $\begin{array}{l}-0.94 \\
(1.38)\end{array}$ & $\begin{array}{l}0.18 \\
(0.52)\end{array}$ & $\begin{array}{l}10.16 \\
(12.39)\end{array}$ & $\begin{array}{l}1.434 \\
(1.39)\end{array}$ & $\begin{array}{l}-1.98 * * \\
(0.72)\end{array}$ & $\begin{array}{l}-1.55^{*} \\
(0.86)\end{array}$ \\
\hline 242 & $\begin{array}{l}-0.83 \\
(0.56)\end{array}$ & $\begin{array}{l}0.881 \\
(0.55)\end{array}$ & $\begin{array}{l}-0.25 \\
(0.21)\end{array}$ & $\begin{array}{l}9.94 * \\
(4.96)\end{array}$ & $\begin{array}{l}-1.22 * * \\
(0.56)\end{array}$ & $\begin{array}{l}0.62 * * \\
(0.29)\end{array}$ & $\begin{array}{l}-0.26 \\
(0.35)\end{array}$ \\
\hline 243 & $\begin{array}{l}-0.65 \\
(0.96)\end{array}$ & $\begin{array}{l}-0.00 \\
(0.95)\end{array}$ & $\begin{array}{l}0.07 \\
(0.36)\end{array}$ & $\begin{array}{l}0.80 \\
(8.57)\end{array}$ & $\begin{array}{l}1.86^{*} \\
(0.96)\end{array}$ & $\begin{array}{l}-1.82^{* * * *} \\
(0.49)\end{array}$ & $\begin{array}{l}0.92 \\
(0.60)\end{array}$ \\
\hline 244 & $\begin{array}{l}-0.89 * \\
(0.44)\end{array}$ & $\begin{array}{l}0.99 * * \\
(0.43)\end{array}$ & $\begin{array}{l}-0.30^{*} \\
(0.16)\end{array}$ & $\begin{array}{l}6.63 \\
(3.91)\end{array}$ & $\begin{array}{l}-0.75 \\
(0.44)\end{array}$ & $\begin{array}{l}0.21 \\
(0.23)\end{array}$ & $\begin{array}{l}0.33 \\
(0.27)\end{array}$ \\
\hline 301 & $\begin{array}{l}1.48 \\
(2.69)\end{array}$ & $\begin{array}{l}-1.57 \\
(2.67)\end{array}$ & $\begin{array}{l}1.00 \\
(1.00)\end{array}$ & $\begin{array}{l}98.11 * * * \\
(24.01)\end{array}$ & $\begin{array}{l}-9.87 * * * \\
(2.70)\end{array}$ & $\begin{array}{l}4.66^{* * * *} \\
(1.39)\end{array}$ & $\begin{array}{l}-2.69 \\
(1.67)\end{array}$ \\
\hline 302 & $\begin{array}{l}'-5.83 \\
(9.25)\end{array}$ & $\begin{array}{l}1.79 \\
(9.17)\end{array}$ & $\begin{array}{l}-1.50 \\
(3.45)\end{array}$ & $\begin{array}{l}-73.76 \\
(82.59)\end{array}$ & $\begin{array}{l}3.21 \\
(9.28)\end{array}$ & $\begin{array}{l}0.77 \\
(4.77)\end{array}$ & $\begin{array}{l}3.79 \\
(5.76)\end{array}$ \\
\hline 304 & $\begin{array}{l}-0.47 \\
(0.83)\end{array}$ & $\begin{array}{l}0.79 \\
(0.83)\end{array}$ & $\begin{array}{l}-0.488 \\
(0.31)\end{array}$ & $\begin{array}{l}18.95 * * \\
(6.84)\end{array}$ & $\begin{array}{l}-1.09 \\
(0.79)\end{array}$ & $\begin{array}{l}0.23 \\
(0.41)\end{array}$ & $\begin{array}{l}-0.33 \\
(0.51)\end{array}$ \\
\hline
\end{tabular}

The short-run and long-run coefficient estimates are reported in Table II and some other diagnostic statistics in 
Table III. As we can see from Table II, if there is at least one short-run coefficient that is significant at $10 \%$ levels of the significance, we regard that the industry has been proved with the short-run coefficient. The empirical results show that the real Bilateral exchange rate has short-run J-Curve effects on the trade balance of almost all the industries, excluded industries coded 111, 122, 124, 241, 243 and 302. So that there are 13 out of 19 industries can be proved with a short-run J-Curve effects of devaluation of Australia Dollar per Chinese Yuan.

The J-Curve phenomenon is indicated where the cases have positive estimates of coefficients at lower lags and then changed into negative one at higher lags (BahmaniOskooee, Ratha, 2004) [18]. As we can seen from Table II, only industries coded 121 and 123 has shown this restricted definition. However, if we follow the J-Curve definition of a negative short-term effect of the balance of trade combined with a long-term positive effect of balance of trade, it is easy to examine that industries coded 123, 232, 233, 241 carries significant positive coefficients, in which are shown with the J-Curve effect.

To test the cointegration relationship between trade balance and real exchange rate, this paper uses F-test to see whether the calculated F-statistics can be greater than the critical value of 2.152 (the upper bound critical value of $F$ test at the $90 \%$ confidence level). As shown in Table III, The F statistics are greater than 2.152 for $84.2 \%$ of the industries (16 out of 19), this means that all the inferences above gain validity. Thus, almost all the coefficient estimates are stabled.

TABLE III: DIAGNOSTIC STATISTICS

\begin{tabular}{|c|c|c|c|c|c|c|c|c|c|c|c|}
\hline Code & Adj. $R^{\wedge} 2$ & $\mathrm{~F}$ & Sig. I & DW & ecm(-1) & Code & Adj. $R^{\wedge} 2$ & $\mathrm{~F}$ & Sig. F & DW & $\operatorname{ecm}(-1)$ \\
\hline 111 & 0.60 & 4.21 & 0.01 & 0.83 & $\begin{array}{l}0.469 * * * \\
(-0.093)\end{array}$ & 232 & 0.70 & 6.45 & 0.00 & 0.78 & $\begin{array}{l}0.129 * \\
(-0.072)\end{array}$ \\
\hline 112 & 0.95 & 51.97 & 0.00 & 2.20 & $\begin{array}{l}1.431 \\
(-1.959)\end{array}$ & 233 & 0.92 & 31.58 & 0.00 & 1.55 & $\begin{array}{l}0.064^{*} \\
(-0.037)\end{array}$ \\
\hline 113 & 0.75 & 8.45 & 0.00 & 1.59 & $\begin{array}{l}-0.105 \\
(-0.609)\end{array}$ & 241 & 0.85 & 15.60 & 0.00 & 0.84 & $\begin{array}{l}-0.017 \\
(-0.064)\end{array}$ \\
\hline 114 & 0.58 & 3.84 & 0.01 & 1.05 & $\begin{array}{l}-0.151 \\
(-0.166)\end{array}$ & 242 & 0.51 & 2.91 & 0.04 & 1.31 & $\begin{array}{l}-0.003 \\
(-0.059)\end{array}$ \\
\hline 121 & 0.14 & 0.46 & 0.83 & 0.61 & $\begin{array}{l}0.164 * * \\
(-0.072)\end{array}$ & 243 & 0.90 & 26.25 & 0.00 & 0.87 & $\begin{array}{l}1.266^{* * *} \\
(-0.521)\end{array}$ \\
\hline 122 & 0.19 & 0.65 & 0.69 & 0.74 & $\begin{array}{l}-0.049 * * \\
(-0.023)\end{array}$ & 244 & 0.83 & 13.65 & 0.00 & 1.50 & $\begin{array}{l}3.763 * * * \\
(-0.786)\end{array}$ \\
\hline 123 & 0.63 & 4.84 & 0.01 & 1.69 & $\begin{array}{l}0.000 \\
(0.000)\end{array}$ & 301 & 0.34 & 1.46 & 0.25 & 0.75 & $\begin{array}{l}-0.007 \\
(-0.005)\end{array}$ \\
\hline 124 & 0.82 & 12.59 & 0.00 & 0.91 & $\begin{array}{l}-0.003 \\
(-0.003)\end{array}$ & 302 & 0.47 & 2.52 & 0.06 & 1.98 & $\begin{array}{l}0.109 \\
(-0.238)\end{array}$ \\
\hline 231 & 0.45 & 2.32 & 0.08 & 1.67 & $\begin{array}{l}0.094 \\
(-0.116)\end{array}$ & 304 & 0.74 & 7.94 & 0.00 & 1.60 & $\begin{array}{l}-0.865 * * * \\
(-0.306)\end{array}$ \\
\hline
\end{tabular}

\section{SUMMARY AND CONCLUSION}

\section{A. Summary}

A country's trade balance cannot be improved after the currency depreciation due to the J-Curve effect. Only after the adjustment lags are realized, the country can improve its trade balance. China is said to manipulate its currency movements in order to gain more export competitiveness. Previous studies failed to mention the link between Chinese exchange rate and its trade balance with other countries of the the world. Till now, no evidence of short-run J-Curve effect pattern was discovered, and the long-run effect were favourable only in the trade balance between China and Australia, France and the US. Those studies attempt to reveal the J-Curve effects of China were mostly futile.

This study contributes to the literature on the aspect of the relationship between the bilateral real exchange rate and trade balance. And considered the trade balance between China and Australia in this article and suspect that the lack of long-run relation between their trade balance could be attribute to another aggregation bias. The results show that there is no single pattern of the trade balance between China and Australia and the real exchange rate.

In conclusion, there are 13 industries can be proved with short-run J-Curve effects and 4 industries can be proved with long-run J-Curve effects of devaluation of Australia Dollar per Chinese Yuan. Only industries coded 123, 232 and 233 has the short-run J-Curve effects which lasted into long-run. However, there are 5 industries coded 113, 114, 231, 244 and 302 are found to have the inverse J-Curve effects that there is a positive relationship between short-run balance of trade and the exchange rate (those industries with a negative sign for the coefficient estimate) and a negative relationship in the long-run (those industries with a positive sign for the coefficient estimate). Further research can be carried on to analysis the links and reasons between J-Curve and inverse J-Curve effects among multiple countries.

\section{B. Suggestions}

By examining the data of different industries that are traded between China and Australia, this paper found different J-Curve phenomenons. Therefore, i suggest future studies to focus on analyzing the J-Curve effects by disaggregate all the traded industries in order to diminish the aggregation bias. In the real economic life, the balance of trade between China and Australia will not only be affected by the fluctuation of the bilateral exchange rate, but also depends on the degree of response of the supply price. Since China and Australia signed the free trade agreement in 2014, the J-Curve effect is amplified by the trade agreement because of the agreed supply prices. After the devaluation of Chinese Yuan, the real expense of Australia import from China will decrease and 
Australia will import more Chinese products as the import prices are fixed in the trade agreement.

An effective control of the fluctuation in bilateral AUD CNY exchange rate would help to reduce the trade volatility between China and Australia. As we can see from the empirical analysis part, due to the time lag effect, the devaluation of Chinese Yuan has little long-run effects on the trade balance between China and Australia. So, if there is an abnormal fluctuation of exchange rate, the trade balance will not be affected significantly. To develop economic and trade relations between China and Australia, we need to adapt to the transformation process of the two countries and shift the focus of trade types from resources to services. I believe that a friendly and harmonious trade relationship would bring opportunities for bilateral service trade cooperation between China and Australia.

\section{REFERENCES}

[1] R. F. Engle and C. W. J. Granger, "Co-integration and error correction: Representation, estimation, and testing," Econometrica, vol. 55, no. 2, pp. 251-276, 1987.

[2] S. P. Magee, "Currency contracts, pass-through, and devaluation," Brookings Papers on Economic Activity, vol. 1, pp. 303-325, 1973.

[3] Z. Zhang, "Does devaluation of the Renminbi improve China's balance of trade?" Economia Internazionale, vol. 51, no. 3, pp. 437-445, 1998.

[4] W. X. Wei, "An empirical study of the foreign trade balance in China," Applied Economics Letters, vol. 6, no. 8, pp. 485-490, 1999.

[5] J. C. Brada, A. M. Kutan, and S. Zhou, "China's exchange rate and the balance of trade," Economics of Planning, vol. 26, no. 3, pp. 229-242, 2004.

[6] T. Demirden and I. Pastine, "Flexible exchange rates and the J-curve: An alternative approach," Economics Letters, vol. 48, no. 3-4, pp. 373-377, 1995

[7] M. H. Pesaran, "Bounds testing approaches to the analysis of level relationships," Journal of Applied Econometrics, 1999, vol. 16, no. 3 , pp. 289-326.
[8] S. Narayan and P. K. Narayan, "An empirical analysis of Fiji's import demand function," Social Science Electronic Publishing, vol. 32, no. 2, pp. 158-168, 2005.

[9] G. Alessandria, "The dynamics of the U.S. trade balance and real exchange rate: The J curve and trade costs?" 2016.

[10] J. Iqbal et al., "Commodity trade between Pakistan and the US: Is there evidence of the J-curve?" Applied Economics, vol. 48, no. 11, pp. 957-965, 2016.

[11] N. Q. My, M. Sayim, and H. Rahman, "The impact of exchange rate on market fundamentals: A case study of J-curve effect in Vietnam," vol. 9, no. 1, p. 45, 2017.

[12] J. Ahmad and J. Yang, "Estimation of the J-Curve in China," Economics Study Area Working Papers, p. 5, 2004.

[13] P. K. Narayan, "Examining the relationship between trade balance and exchange rate: the case of China's trade with the USA," Applied Economics Letters, vol. 13, no. 8, pp. 507-510, 2006.

[14] Y. Wang "The J curve: China versus her trading partners," Bulletin of Economic Research, vol. 58, no. 4, pp. 323-343, 2010.

[15] R. Zhang et al., "Is there J-Curve effect in the commodity trade between Korea and rest of the world?" Economic Change \& Restructuring, vol. 47, no. 3, pp. 227-250, 2014.

[16] M. Aftab et al., "Asymmetry cointegration and the J-curve: New evidence from Malaysia-Singapore commodity trade," Journal of Economic Asymmetries, vol. 14, 2016.

[17] B. Panda and D. R. K. Reddy, "Dynamics of India-China trade relations: Testing for the validity of marshall-lerner condition and J-Curve hypothesis," Iup Journal of Applied Economics, vol. 15, 2016.

[18] M. B. Oskooee and A. Ratha, "The J-Curve: A literature review," Applied Economics, vol. 36, no. 13, pp. 1377-1398, 2004.

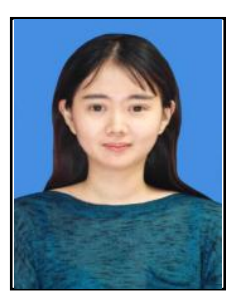

Sihong Wu was born in Guangdong, China in Jul 1993. She is a Ph.D candidate of Management and Commerce in Murdoch University, Western Australia, 6150. He gets the Academic Master of Finance from Guangdong University of Economics \& Finance, Guangzhou China, 51000; The master of Applied finance from the University of Western Australia, Western Australia, 6003.

Her research interests include trading and markets, international finance and multinational corporate governance. She is a tutor of Macro and micro economics in Chinese WenDu Kaoyan institutions and used to be a lecturer of International Trade in Guangdong vocational college. 